\title{
Confidential Information and the Right to Freedom of Speech
}

\author{
Svitlana Bevz ${ }^{1, *}$, Oleksandr Tereshchuk², Oleksiy Kravchuk ${ }^{1}, V^{2}$ alentyna Yehorova ${ }^{1}$, \\ Inna Bodnarchuk ${ }^{1}$ and Mykola Danevych ${ }^{2}$
}

\author{
${ }^{1}$ National Technical University of Ukraine, Igor Sikorsky Kyiv Polytechnic Institute, Ukraine \\ ${ }^{2}$ Interregional Academy of Personnel Management, Kyiv, Ukraine
}

\begin{abstract}
The article is devoted to the problem of ensuring balance in the realization of two fundamental human rights and freedoms in a democratic society - the right to freedom of speech and privacy. It has been concluded that the rights to freedom of speech and privacy are recognized as fundamental human rights that do not conflict with each other but are intangible, inherent in every person. The right to freedom of journalism is a continuation of the right to freedom of speech and information and consists in the collection, storage, and dissemination of socially important information through the mass media. The usage of the rights in question, including in the mass media actions, may not be grounds for restricting or violating the right of everyone to privacy, the confidentiality of correspondence, correspondence, telephone conversations, and entails criminal liability in cases provided by law. In the public interest, the law provides grounds for exempting a journalist from criminal liability for disclosing confidential information, in particular in the case of disclosure of information of public interest or has already been published in other media, or concerns officials of public authorities.
\end{abstract}

Keywords: Freedom of speech, freedom of information, confidential information, crime, criminal liability, journalism.

\section{INTRODUCTION}

Freedom of thought and speech, the right to freely collect, store, use, and disseminate information are an integral part of natural human rights and freedoms. The whole history of mankind is connected with the accumulation and transmission of information from one generation to another, which has ensured the cultural and technological development of the human race. This right is enshrined in the Basic Laws of almost all countries. The First Amendment to the Constitution of the United States of America, approved in 1791, states: "Congress cannot pass any law that ... restricts freedom of speech or the press" (Richter A.G. 2011).

Article 21 of the Constitution of the Italian Republic declares: "Everyone has the right to express their views orally, in writing and in any other way. The press may not be subject to permission or censorship. Confiscation is possible only on the basis of a motivated act of the judiciary... Printed works, spectacles and all other events that contradict morality are prohibited" (Richter A.G. 2011).

Article 5 of the German Constitution states: "Everyone has the right to freely express and disseminate their opinion orally, in writing or in the form of a photograph..." (Richter A.G. 2011).

This right is enshrined in Art. 34 of the Constitution of Ukraine: "Everyone has the right to freely collect,

*Address correspondence to this author at the National Technical University of Ukraine, Igor Sikorsky Kyiv Polytechnic Institute, Ukraine;

E-mail:maxnik8888@gmail.com store, use, and disseminate information orally, in writing or otherwise - at their discretion". The confirmation of the importance and value of this right is the establishment of criminal liability for obstructing the activities of journalists, encroaching on their lives, health, freedom, or property (Art. 171, 345-1, 347-1, 348-1, and 349-1 of the Criminal Code of Ukraine).

At the same time, the right in question cannot be absolute and unlimited. Our right ends where another person's right begins. Part 2 of Art. 34 of the Constitution of Ukraine states that the exercise of the right to freedom of speech may be restricted by law in the interests of national security, territorial integrity, or public order in order to prevent riots or crimes, to protect public health, to protect the reputation or rights of others, to prevent disclosure information obtained in confidence, or to maintain the authority and impartiality of justice. It means that the right to freedom of speech, collection, and dissemination of information, including the mass media, in any democratic society has its limitations, the scope of which depends on other human rights and freedoms, the needs of society and the state.

In the legal literature, the problem of the legal protection of freedom of speech, including the activities of the media, attention was paid by such scholars as $P$. Berzin, R. Veresha, S. Golovatyi, S. Likhova, T. Lazutina, A. Marushchak, L. Kostenko, O. Krasilnikova, D. Kukushkin, N. Kushakova, V. Pavlykivsky, however, a number of issues of legal restriction of freedom of speech and professional activity of journalists still remain unresolved. 
The aim of the study is to establish the legal limits of freedom of speech and journalism in the context of criminal liability for violations in the field of circulation of confidential information.

Objectives of the study include analysis of current criminal legislation on legal restrictions on the collection, storage, and dissemination of confidential information.

\section{METHODS}

The Law of Ukraine "On Access to Public Information" recognizes confidential information as a type of information with limited access. According to Part 1 of Art. 7 of the mentioned law, confidential information is the information to which access is restricted by a natural or legal person, except for subjects of power, and which may be disseminated in the manner prescribed by them at their request in accordance with the conditions provided by them. Information managers who possess confidential information may disseminate it only with the consent of those who have restricted access to the information, and in the absence of such consent - only in the interests of national security, economic prosperity, and human rights.

The current legislation does not contain a clear and exhaustive list of types of personal information that can be considered confidential, nor does it determine the procedure for recognizing certain types of personal information as confidential information. According to Art. 11 of the Law of Ukraine "On Information", confidential information about an individual includes, in particular, data on their nationality, education, marital status, religious beliefs, health status, as well as address, date, and place of birth. Confidential information about a person is information with limited access, which was confirmed by the official interpretation of the law "On Information" by the Constitutional Court of Ukraine dated October 30, 1997, № 5-3ா /97, which states that not only the collection but also storage is prohibited, usage, and dissemination of confidential information about a person without their consent, except as provided by law, and only in the interests of national security, economic well-being, human rights, and freedoms. Confidential personal information includes health, property, religion, marital status, education, date and place of birth, and other personal information. The authors of scientific and practical comments offer a broader list of information that can be classified as confidential. In particular, it is information about a person's private life, property status, intimate relations, and any other information related to a person's lifestyle and not of a public nature. The expanded interpretation of information included in the content of confidential information is evidenced by Art. 7 of the Law of Ukraine "On Access to Public Information", which stipulates that confidential information is information to which access is restricted by the individual, that is, in many cases, the person themselves shall determine the content and limits of dissemination of information that is considered confidential. The vague, descriptive nature of determining the content of confidential information causes significant difficulties in the activities of the mass media and other areas (including activities in the field of trade, services), and this, in turn, complicates the legal assessment of immunity of privacy.

Recently, the state has been actively trying to realize the rights and freedoms of journalists by imposing responsibilities on institutions and organizations to provide objective information about their activities, increasing criminal liability for obstructing the activities of the media. For example, according to the Law of Ukraine "On Ensuring the Right to a Fair Trial" (Law of Ukraine 2015), the mass media have the right to film in a courtroom without technical permission by technical means, but the full broadcast of the court hearing should still be carried out only with the judge's permission. The value of the obtained information of the journalist is measured by its reliability. Sources of information of a journalist can be both publicly available and with limited access (secret, official, confidential information). The right of a journalist to request information from official sources is provided by the Laws of Ukraine "On Access to Public Information" and "On Appeals of Citizens".

Reporting in various mass media about the commission of crimes and offenses long before the trial in court has become a common practice and wideranging in Ukraine. This information is disseminated not only by journalists and politicians but also by those who are expressly prohibited by law and judicial ethics from doing so (lasechko et al. 2020). At the same time, ignoring the basic rules of judicial ethics, specific names are called, opinions are heard about the degree of guilt of specific persons, the actual circumstances of the act are described, the qualification of actions is determined and opinions are expressed not only about punishment but also about what should be done by courts and judges. 
The Civil Code of Ukraine guarantees the human right to secrecy of health. Today, the mass media reports about the health of individuals and the presence of a certain disease have become relevant. Thus, according to the decision of the Board of Judges of the Judicial Chamber for Civil Cases of the Court of Appeal of Lviv region dated November 21, 2016, № № 22 -ts/783/5959/16, the claim of a person to a journalist who, using surveillance and secret video, using the inexperience of the nurse on duty, illegally filmed and later disclosed the information contained in the medical documents of the victim, was satisfied.

Increasingly, there are reports in the mass media about the general statistics of the spread of COVID-19, as well as the indication of specific names without the consent of the person, which is a direct violation of the law (lasechko et al. 2020).

To ensure effective protection of information about a person's personal life, the legislation provides for criminal liability for illegal collection, storage, usage, destruction, dissemination of confidential information about a person or illegal change of such information (Article 182 of the Criminal Code of Ukraine), illegal disclosure of medical secrets (Article 145 of the Criminal Code of Ukraine), violation of the secrecy of correspondence, telephone conversations, telegraph or other correspondence transmitted by means of communication or computer (Article 163 of the Criminal Code of Ukraine), disclosure of the secret of adoption (Article 168 of the Criminal Code of Ukraine), interference in the activities of judicial bodies (Article 376 of the Criminal Code of Ukraine), etc. Thus, the Constitution of Ukraine and criminal law prohibit the publication of confidential information about a person without their consent, which means the highest level of protection of the human right to privacy, including in the case of a journalist exercising their rights to collect, store, and disseminate information (lasechko et al. 2020).

At the same time, the right of people to receive socially significant information in certain cases outweighs the criminal law protection of information about private life and provides for certain exceptions to these rules regarding the activities of journalists. The problem of the conflict between a journalist's right to gather information and the right to privacy has long been known. If we look at the practice of the ECtHR, the relevant court decisions have been made since the 60 s of the last century. Often the court takes the side of ensuring the freedom of speech. Thus, most European countries, taking into account the decisions of the European Court of Human Rights, distinguish between information about private life and information of public interest (Austria, Germany, Spain, and the Netherlands). The latter can be published regardless of the wishes of the person (lasechko et al. 2020). The ECtHR states that the authorities should be more tolerant of criticism (Law of Ukraine 1986), As a result, politicians were asked to accept attacks on them personally and interference in their private lives for the sake of freedom of expression and dissemination of information.

Art. 6 of the Law of Ukraine "On Access to Public Information" (Law of Ukraine 2011), allows restrictions on access to information in compliance with the set of the following requirements:

1) solely in the interests of national security, territorial integrity, or public order in order to prevent riots or crimes, to protect public health, to protect the reputation or rights of others, to prevent the disclosure of confidential information, or to maintain the authority and impartiality of justice;

2) disclosure of information could cause significant harm to these interests;

3) the damage from the disclosure of such information outweighs the public interest in obtaining it.

The absence of at least one of these requirements makes it impossible to restrict access to information.

In addition, Art. 42 of the Law of Ukraine "On Printed Media (Press) in Ukraine" (Law of Ukraine 1992), provides for the release of a journalist from liability for publication, if this information:

- $\quad$ is a literal reproduction of materials published by another printed media with reference to it;

- discloses a secret that is specifically protected by law but this information was not obtained by a journalist illegally;

- $\quad$ the law provides for dismissal or non-prosecution for such actions.

\section{CONCLUSION}

The current legislation of Ukraine, recognizing the right to freedom of speech and information as one of 
the basic natural human rights, provides for appropriate legal restrictions in case of abuse of the latter. One of the main problems of this right is to maintain a balance between the right to freedom of speech and privacy, including in the activities of the mass media.

The most effective protection of the right to privacy should be the establishment of criminal liability for the illegal collection, storage, usage, destruction, dissemination of confidential personal information, or illegal alteration of such information (Article 182 of the Criminal Code of Ukraine). At the same time, these restrictions have an additional "cooling effect" on the journalist's activities for the collection, storage, and dissemination of socially significant information.

In accordance with current legislation, the following additional grounds for dismissal of a journalist under Art. 182 of the Criminal Code of Ukraine should be recognized:

- disclosure of confidential information of public interest;

- disclosure of confidential information that concerns officials and affects the evaluation of their official activities;

- disclosure of confidential information that has already been published in other mass media;

- disclosure of confidential information obtained legally.

These circumstances must be enshrined in criminal law as appropriate grounds for exemption from criminal liability for acts under Art. 182 of the Criminal Code of Ukraine.

\section{REFERENCES}

Law of Ukraine "On Ensuring the Right to a Fair Trial" № 192-VIII of 12.02.2015. (https://zakon.rada.gov.ua/laws/show/19219\#Text).

Law of Ukraine № 2782-XII. "On Printed Media (Press) in Ukraine". Retrieved November 16, 1992. (https://zakon.rada.gov.ua/ laws/show/2782-12\#Text).

Law of Ukraine № 2939-VI1. "On Access to Public Information". Retrieved January 3, 2011. (https://zakon.rada.gov.ua/laws/ show/2939-17\#Text)

Richter, A.G. 2011. "International standards and foreign practice of regulation of journalism“. Novosti” Printing House.

S. lasechko, I. Bratsuk, S. Petrechenko, I. Kazanchuk and R. Liashenko, 2020. "Development of the Doctrine on Certain Personal Incorporeal Rights in European Countries“. Journal Of Advanced Research In Law And Economics 11(4):11691174.

https://doi.org/10.14505//jarle.v11.4(50).12

S. lasechko, M. Haliantych, V. Skomorovskyi, V. Zadorozhnyi, O. Obryvkina and O. Pohrebniak, 2020. "Contractual Relations in the Information Sphere". SRP 11(8): 301-303.

S. lasechko, O. Zaitsev, V. Kozhevnykova, K. Melnyk, O. Kulchii, 2020. "Transactions with the Personal Non-Property Right". SRP11(10): 49-52. https://doi.org/10.14505//jarle.v11.4(50).12

S. lasechko, T. Stepanenko, V. Korolova, N. Makovetska and O. Chernetchenko, 2020."Features of Legal Regulation Transplantations in Ukraine". Journal Of Critical Reviews 7(13): 430-432. https://doi.org/10.31838/jcr.07.13.76

S. lasechko, V. Puzyrnyi, N. Puzyrna, N. Kostiuk, I. Bakhnovska and I. Litvinova, 2020. "The Investigation Of Peculiarities Of The Occurrence Of Subjective Civil Rights In Registration Of A Patent". Journal Of Advanced Research In Law And Economics 11(3): $844-849$. https://doi.org/10.14505/jarle.v11.3(49).17

S. lasechko, Vitalii B. Skomorovskyi, Ihor Andronov, Oleksii Zaitsev and Oksana Bortnik, 2020. "Features Of The Subjective Civil Rights On Patent". Journal Of Critical Reviews 7 (13): 297299.

https://doi.org/10.31838/jcr.07.13.50

\begin{tabular}{lll}
\hline Received on 16-02-2021 & Accepted on 25-02-2021 & Published on 08-03-2021
\end{tabular}

\section{https://doi.org/10.6000/1929-4409.2021.10.75}

(C) 2021 Bevz et al.; Licensee Lifescience Global.

This is an open access article licensed under the terms of the Creative Commons Attribution Non-Commercial License (http://creativecommons.org/licenses/by-nc/3.0/) which permits unrestricted, non-commercial use, distribution and reproduction in any medium, provided the work is properly cited. 